\title{
Extranodal Marginal Zone Lymphoma of Mucosa-Associated Lymphoid Tissue by Ann Arbor Stage
}

National Cancer Institute

\section{Source}

National Cancer Institute. Extranodal Marginal Zone Lymphoma of Mucosa-Associated Lymphoid Tissue by Ann Arbor Stage. NCI Thesaurus. Code C141260.

An anatomic stage for extranodal marginal zone lymphoma of mucosa-associated lymphoid tissue based on the Ann Arbor classification criteria. 